\title{
Suitability of tetrazolium test for Tamarindus indica L. seeds
}

\section{Adequação do teste de tetrazolium para sementes de Tamarindus indica L.}

\author{
Luciana Nunes Cordeiro ${ }^{1 *}$; Riselane de Lucena Alcântara Bruno2; Lucas Kennedy \\ Silva Lima3; Albericio Pereira de Andrade3; Karialane da Silva Belarmino4; \\ Edna Ursulino Alves ${ }^{2}$
}

\section{Highlights}

Developing of a tetrazolium test protocol to evaluate Tamarindus indica L. seeds.

Preconditioning in distilled water for $48 \mathrm{~h}$ to remove the seed coat.

Tetrazolium test allowed differentiating seed lots regarding viability.

\begin{abstract}
Seed quality is routinely assessed by direct tests, e.g, the germination test, or indirect tests like the tetrazolium test, which has shoown to be promising in the determine viability and vigor, allowing the diagnosis of the main problems that may affect seed quality, such as mechanic damages, field deterioration and storage. In this respect, this study was conducted to develop a tetrazolium test protocol to evaluate the viability and vigor of Tamarindus indica L. seeds. Before exposing the seeds to the tetrazolium solution, seed preconditioning studies were carried out in which seven soaking times were tested. The soaking time that did not cause damage to the seed embryo and allowed the removal of the seed coat to expose the seed structures to the tetrazolium salt was selected. Then, an experiment was set up in a completely randomized design with a $2 \times 3 \times 3$ factorial arrangement involving two seed lots, three soaking times in tetrazolium salt $(6,12$ and $16 \mathrm{~h})$ and three salt concentrations $(0.075,0.1$ and $0.5 \%)$, totaling 18 treatments with four replicates of 25 seeds, evaluated at $40^{\circ} \mathrm{C}$. For each treatment, the seeds were divided into three classes, namely, viable and vigorous embryos (class 1); viable embryos (class 2) and non-viable or dead embryos (class 3). For a comparison with the tetrazolium test results, the two seed lots were analyzed for water content, germination, emergence, first count, germination speed index, emergence speed index, growth and seedling dry weight. The viability and vigor of $T$. indica seeds can be evaluated after a soaking period

1 Profa, Instituto Federal de Educação, Ciência e Tecnologia do Sertão Pernambucano, IFSertãoPE, Salgueiro Campus, Salgueiro, PE, Brazil. E-mail: luciana.nunes@ifsertao-pe.edu.br

2 Profas Dras, Postgraduate Program in Agronomy, Universidade Federal da Paraíba, UFPB, Areia, PB, Brazil. E-mail: lanebruno.bruno@gmail.com; ednaursulino@cca.ufpb.br

3 Profs. Drs., Universidade Federal do Agreste de Pernambuco, UFAPE, Cruz das Almas, BA, Brazil. E-mail: lucas18kennedy@gmail.com; albericio3@gmail.com

${ }^{4}$ Dra. Researcher, Postgraduate Program in Agronomy, UFPB, Areia, PB, Brazil. E-mail: karialane@hotmail.com

* Author for correspondence
\end{abstract}

Received: July 17, 2021 - Approved: Nov. 15, 2021 
of $48 \mathrm{~h}$ and immersion for $6 \mathrm{~h}$ in tetrazolium salt at the concentration of $0.1 \%$, at $40^{\circ} \mathrm{C}$, with provides results similar to conventional seed viability tests. The tetrazolium test proved to be adequate to differentiate $T$. indica seed lots in terms of viability.

Key words: Emergency. Fabaceae. Fruitful species. Germination. Physiological quality.

\section{Resumo}

A qualidade das sementes é avaliada rotineiramente por testes diretos como o de germinação e indiretos como o teste de tetrazólio que tem se mostrado promissor na determinação da viabilidade e vigor possibilitando o diagnóstico dos principais problemas que podem afetar a qualidade das sementes, como danos mecânicos, deterioração de campo e armazenamento. Neste sentido, objetivou-se com este trabalho desenvolver um protocolo do teste de tetrazólio para avaliar a viabilidade e o vigor das sementes de Tamarindus indica L. Antes da exposição das sementes a solução de tetrazólio, foram realizados estudos pre-condicionamento das sementes utilizando sete períodos de embebição sendo selecionado o tempo que não causou danos ao embrião da semente e permitiu a remoção do tegumento para exposição das estruturas da semente ao sal de tetrazólio. Em seguida, o experimento foi instalado em delineamento inteiramente casualizado em esquema fatorial $2 \times 3 \times 3$, sendo dois lotes de sementes, três tempos de embebição em sal (6; 12 e 16 horas) e três concentrações de sal de tetrazólio $(0,075 ; 0,1$ e 0,5\%), totalizando dezoito tratamentos com quatro repetições de 25 sementes, avaliados a $40{ }^{\circ} \mathrm{C}$. Para cada tratamento as sementes foram divididas em três classes: embriões viáveis e vigorosos (classe 1); embriões viáveis (classe 2) e embriões inviáveis ou mortos (classe 3). Para comparar com o resultado do teste de tetrazólio os dois lotes de sementes foram submetidos a análise de teor de água, germinação, emergência, primeira contagem e índice de velocidade de germinação e emergência, crescimento e massa seca de plântulas. A viabilidade e o vigor das sementes de $T$. indica podem ser avaliados após um período de $48 \mathrm{~h}$ de embebição e $6 \mathrm{~h}$ de imersão na concentração de $0,1 \%$ de sal de tetrazólio a $40^{\circ} \mathrm{C}$, com resultados semelhantes aos testes convencionais de determinação da viabilidade das sementes. $O$ teste de tetrazólio mostrou-se adequado para diferenciar a viabilidade em relação aos lotes de sementes de $T$. indica.

Palavras-chave: Espécie frutífera. Emergência. Fabaceae. Germinação. Qualidade fisiológica.

\section{Introduction}

Tamarind (Tamarindus indica L.) a fruit species distributed in tropical, subtropical and semiarid regions, is considered ideal for exploitation in low rainfall regions, as it tolerates from five to six months of drought (A. V. C. Silva et al., 2016). It is propagated mainly via seeds, with gemination occurring between 5 to 38 days after sowing (Mozumder, Khan, \& Rahman, 2018), which constitutes a long process. Thus, the development of rapid tests to characterize seed quality with consistency and reliability is warranted.

Although the germination test is still the main parameter to evaluation seed physiological quality, it is only performed in adequate environmental conditions (humidity, temperature, oxygen, and light) (Paim et al., 2019). In this context, the tetrazolium test was shown to be a promising alternative to determine seed viability and vigor in several tree species, regarding the quality and 
speed of results (Ferro et al., 2019). Besides viability, it provides valuable information about vigor, allowing the diagnosis of the main problems that may affect seed quality, such as mechanical damages, deterioration in the field and storage (França \& Krzyzanowiski, 2019).

This species is considered a component of agroforestry due to its nitrogen fixation capacity, establishment in low-fertility soils and erosion control (Singh, 2015). The tamarind heartwood is very durable and used in the manufacture of furniture and tent pegs (Yusuf et al., 2019). In addition, it is highly valued mainly for its fruits, especially the pulp, which is used for a wide variety of domestic and industrial purposes (Ramchander et al., 2012). Tamarind has a wide range of medicinal applications, in addition to containing high levels of vitamin B and $\mathrm{C}$, several carbohydrates, fats, proteins, tannins, acids and minerals, which are found in different parts of the plant (Ferreira, Monteiro, Rodrigues, Oliveira, \& Boliani, 2018).

Several studies have developed methodologies to evaluate the efficiency of the tetrazolium test in seeds of the Fabaceae family, e.g., Erythrina velutina Willd. (Cunha \& Gomes, 2015), Libidibia ferrea (Mart. ex Tul.) L.P. Queiroz var. ferrea (Carvalho et al., 2017), Poincianella pyramidalis (Tul.) L. P. Queiroz (Sousa, Bruno, Silva, Torres, \& Andrade, 2017), Senegalia polyphylla (DC.) Britton and Rose (T. L. Lima \& Cunha, 2019), and Piptadenia stipulacea (Benth.) Ducke (Pereira, Paiva, Souza, Benedito, \& Torres, 2020). However, there are no literature reports on the suitability of the tetrazolium for T. indica. Therefore, further in-depth investigations are warranted in this field to accelerate the process of evaluation of seed physiological quality in this species.
In view of the above and in the absence of protocols for the tetrazolium test in $T$. indica seeds, the present study conducted to develop a methodology to evaluate viability and vigor by the tetrazolium test.

\section{Material and Methods}

Seeds were obtained from completely ripe fruits, collected from five mother trees with at the approximate age of 48 years, in the irrigated perimeter of São Gonçalo, located in the Sertão Paraibano region of Paraiba, Brazil (645'33" S, 38०13'41" W, 220 m above sea level).

The fruits used in the study were harvested in October, directly from the five mother trees, when they showed physiological maturity, with the aid of a trimmer and a plastic canvas, following the recommendations of Sousa et al. (2010). The first harvest took place in 2018 (lot 1), and the second in 2019 (lot 2). Still inside the fruits, the lot 1 seeds were packaged in polyethylene bags, which were stored in a controlled environment $(8 \pm 3$ ${ }^{\circ} \mathrm{C}$ e $37 \pm 3 \%$ relative humidity). Late, the seeds of both lots were removed manually from the fruits and sent to the Seed Analysis Laboratory, where their water content was measured. Before being used in the physiological quality tests (germination and vigor), the seeds were subject to mechanical scarification in the region opposite to the hilo (Oliveira, Oliveira, Costa, Santos, \& Guariz, 2017).

The experiment was laid out in an completely randomized design with a $2 \times 3 \times 3$ factorial arrangement consisting of two seed lots, three soaking times in tetrazolium salt $(6$, 12 , and $16 \mathrm{~h}$ ) and three salt concentrations $(0.075,0.1$, and $0.5 \%)$ using four replicates of 25 seeds. 
In the adjustment of methodologies for the preparation, preconditioning and staining of seeds for tetrazolium tests, two treatments were developed: Preparation unscarified seeds (control) and seeds scarified mechanically with no. 80 sandpaper in the region opposite to the hilum; Preconditioning - seeds were placed between sheets of Germitest ${ }^{\circledR}$ paper moistened with an amount of water equivalent to 2.5 times the weight of the non-hydrated paper, covered with a third sheet and directly immersed in distilled water for seven periods $(8,16,24,32,40,48$, and 56 h) in a germination chamber at $30^{\circ} \mathrm{C}$. After the soaking periods, the seed coat was removed with a slight pressure to avoid damaging the embryo.

From a stock solution $(10 \mathrm{~g}$ in $1000 \mathrm{ml}$ of distilled water - 1\%) of 2,3,5-Triphenyltetrazolium chloride, the solutions used in the experimentwere prepared at the concentrations of $0.075,0.1$, and $0.5 \%$, in which the embryos were immersed for 6,12 , and $16 \mathrm{~h}$, in the dark, in a BOD chamber, at 40 ${ }^{\circ} \mathrm{C}$ (Zorzal, Fantinato, Campos, Luz, \& Corte, 2015).

After staining, the embryos were removed and washed in running water, kept in a refrigerator in distilled water until analysis and sectioned lengthwise along the center of the embryonic axis (Figure 1). They are observed individually with a stereoscopic magnifier and evaluated for texture, uniformity and staining intensity. For the latter parameter, the embryos were classified as non-stained, partially stained, adequately stained, and strongly stained, on the tissues.

Staining differentiation was carried out as per Sousa et al. (2017), in which the color of staining was dividedinto brightred or brightpink (live and vigorous tissue), deep carmine (tissue in deterioration) and milky white or yellowish (dead tissue). The seeds were classified in two categories: viable or non-viable, following the coloring patterns proposed above, using photographic camera. Each embryo was classified as: Class 1 - Viable and vigorous seeds (uniform, light pink color embryos with total absence of lesion or more intense or yellowish staining area and strong pink or light red seeds with a firm texture); Class 2 Viable seeds: embryos with superficial lesions on the external part of the cotyledons or in their interior, which do reach the embryonic axis, presence of a yellowish (dead tissue) or intense red (tissue in deterioration) color at the lower apical extremity of the hypocotyl-radicle axis, not affecting the central cylinder, grooves of intense red color on the hypocotyl-radicle axis, only reaching the cortex and embryo exhibiting lesions on one or both cotyledons, in an extension lower than the total half of the seeds, with the embryonic axis showing normal and firm appearance; and Class 3 Not viable seeds (embryos with deteriorated or dead tissue on the internal surface of the cotyledons and dead embryos, with no respiration detected in any of the tissues. Viability was expressed as a percentage of viable seeds. 


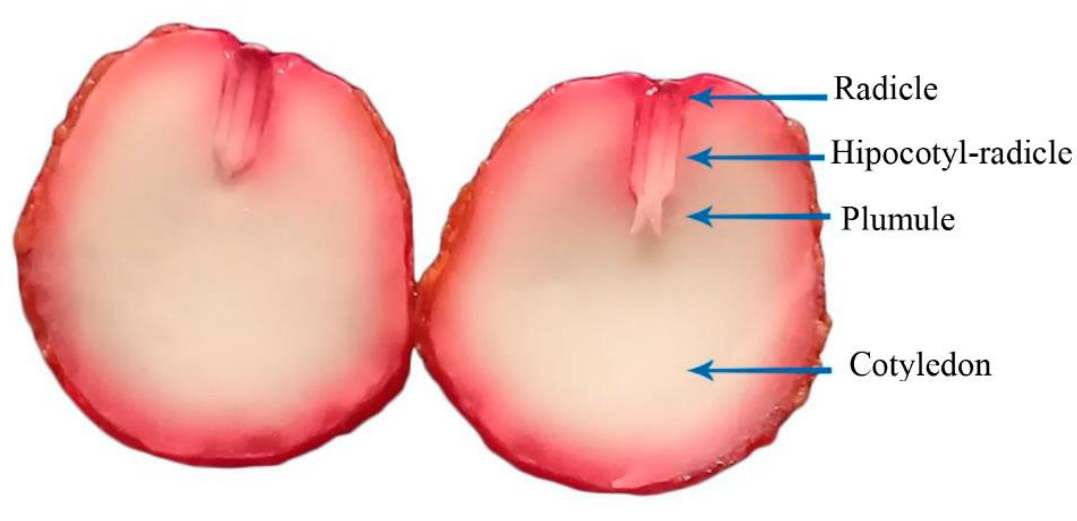

\section{$0,5 \mathrm{~cm}$}

Figure 1. Internal structures of Tamarindus indica L. embryo stained for $6 \mathrm{~h}$ in tetrazolium salt solution at a concentration of $0.1 \%$

Seed moisture degree was determined by oven-drying at $105 \pm 3^{\circ} \mathrm{C}$, for $24 \mathrm{~h}$ (Ministério da Agricultura, Pecuária e Abastecimento [MAPA], 2009).

Germination was carried out using paper substrate in $\mathrm{BOD}$ chamber at $30^{\circ} \mathrm{C}$, in an adapted of the methodology described by D. D. A. Silva, Machado, Cruz, Vespucci and Araujo (2017). For emergence, sand was used as substrate in plastic trays, in a greenhouse. Germination was evaluated at three-day intervals after sowing and emergency was evaluated by a daily count of normal seedlings, observing the emergence of seedlings cotyledons and hypocotyls until stabilization. Results were expressed as a percentage of normal seedlings (MAPA, 2009).

The first germination and seedlingemergency counts were performed on the third and tenth days after the beginning of the tests, respectively, using normal seedlings as the criterion (MAPA, 2009). The germination
(GSI) and emergence (ESI) speed indices were calculated by the equation proposed by Maguire (1962), as the result of the sum of the ratio germinated seeds every three days until stabilization; and daily counts of emergence of normal seedlings until stabilization.

At the end of the emergency test, the lengths of the primary root and shoots were mensured with a graduated ruler, with results expressed in $\mathrm{cm}$ seedling $^{-1}$. These seedling were later weighed, placed in kraft paper bags and dried in a forced-air oven at constant 65 ${ }^{\circ} \mathrm{C}$ until reaching constant weight to determine the dry weight of root, shoots and seedlings, with results expressed in g seedling ${ }^{-1}$.

Initial data were analyzed as to normal distribution by the Kolmogorov-Smirnov test $(p \leq 0.05)$. Variables without a normal distribution fit were transformed into arcsine $(X / 100)^{1 / 2}$, percentage and $\log (x+1)$, values with continuous distribution. Next, the data were subjected to analysis and means were 
compared by the Tukey's test ( $p \leq 0.05$ ). Physiological quality data was analyzed by Student's t test ( $p \leq 0.05$ ). Sisvar software was used for ANOVA analysis and the meancomparison test.

\section{Results and Discussion}

The T. indica embryos staining process requires previous manual scarification of the seeds. After analysis, preconditioning the seeds by soaking on Germitest ${ }^{\circledR}$ paper moistened with distilled water for $48 \mathrm{~h}$ in a germination chamber at $30^{\circ} \mathrm{C}$ proved to be the most efficient way of removing the seed coat without causing damage to the embryo and cotyledons. Cunha and Gomes (2015) pointed out that soaking time is important not only for the beginning of physiological activities in the seed, but also to favor the removal of the seed coat and the exposure of the embryo to contact with tetrazolium solution.

Analysis of variance for $T$. indica seed viability regarding the lots, immersion times and tetrazolium salt concentrations revealed a significant effects $(P<0.005)$ of the factors in isolation, of the interaction between time and concentration $(\mathrm{TxC})$ and even of the lot $\mathrm{x}$ concentration ( $\mathrm{L} \times \mathrm{C}$ ) interaction at $5 \%$ (Table 1).

Table 1

Summary of analysis of variance for viability in Tamarindus indica L. seeds as a function of lots, immersion times and concentrations of tetrazolium solution

\begin{tabular}{|c|c|c|}
\hline FV & GL & Viability $(Q M)^{1}$ \\
\hline Lot (L) & 1 & $0.1020^{* *}$ \\
\hline Time $(\mathrm{T})$ & 2 & $0.3363^{* *}$ \\
\hline Concentration (C) & 2 & $2.4167^{* *}$ \\
\hline$L \times T$ & 2 & $0.0190^{\text {ns }}$ \\
\hline$L \times C$ & 2 & $0.0228^{*}$ \\
\hline $\mathrm{T} \times \mathrm{C}$ & 4 & $0.0386^{* *}$ \\
\hline $\mathrm{L} \times \mathrm{T} \times \mathrm{C}$ & 4 & $0.0163^{\text {ns }}$ \\
\hline Residual & 54 & 0.0070 \\
\hline \multicolumn{2}{|c|}{ CV (\%) } & 8.16 \\
\hline \multicolumn{2}{|c|}{ Mean (\%) } & 69.93 \\
\hline
\end{tabular}

${ }^{1}$ Data arcsine-transformed $(\operatorname{root}(\mathrm{x} / 100))$ for not fitting to normal distribution by the Kolmogoroy-Smirnov test; ns, * and **: not significant and significant 5 and $1 \%$ of probability by the $F$ test, respectively.

In the decomposition of the LxT interaction, the tetrazolium concentration of $0.075 \%$ in the embryos of both lots stood out, followed by the concentration of $0.1 \%$ for embryos of the 2019 lot. The
$0.1 \%$ concentration allowed distinguishing the viability between lots, with the 2019 lot exhibiting better quality than the 2018 lot (Figure 2). 
In the analysis of the TxC interaction, This was likely due to the longer time of the concentrations $0.075 \%$ and $0.1 \%$ with exposure for $6 \mathrm{~h}$ stood out over the period of 16 $h$, which resulted in a lower viability percentage. exposure to the salt, which complicated the embryo tissues reading process, preventing a clear distinction of viability (Figure 3).

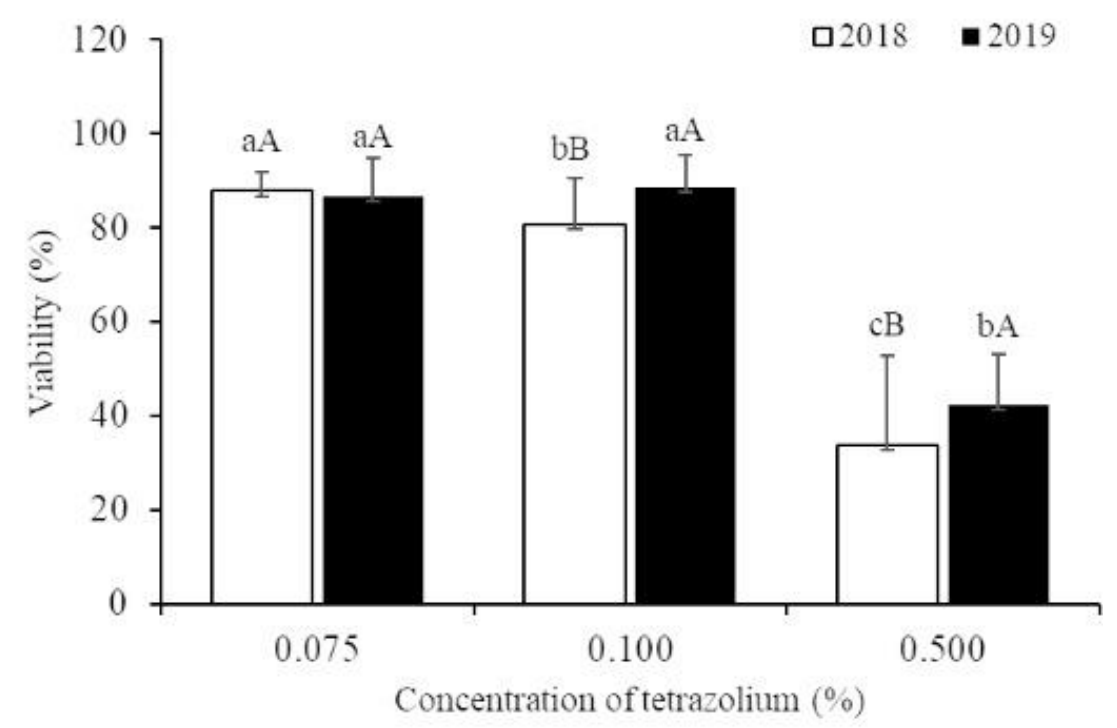

Figure 2. Mean viability of Tamarindus indica L. seeds under the lot $x$ tetrazolium salt concentration interaction. Means followed by the same lowercase letter between concentrations and uppercase letters between lots do not differ by Tukey's test ( $p \leq 0.05)$.

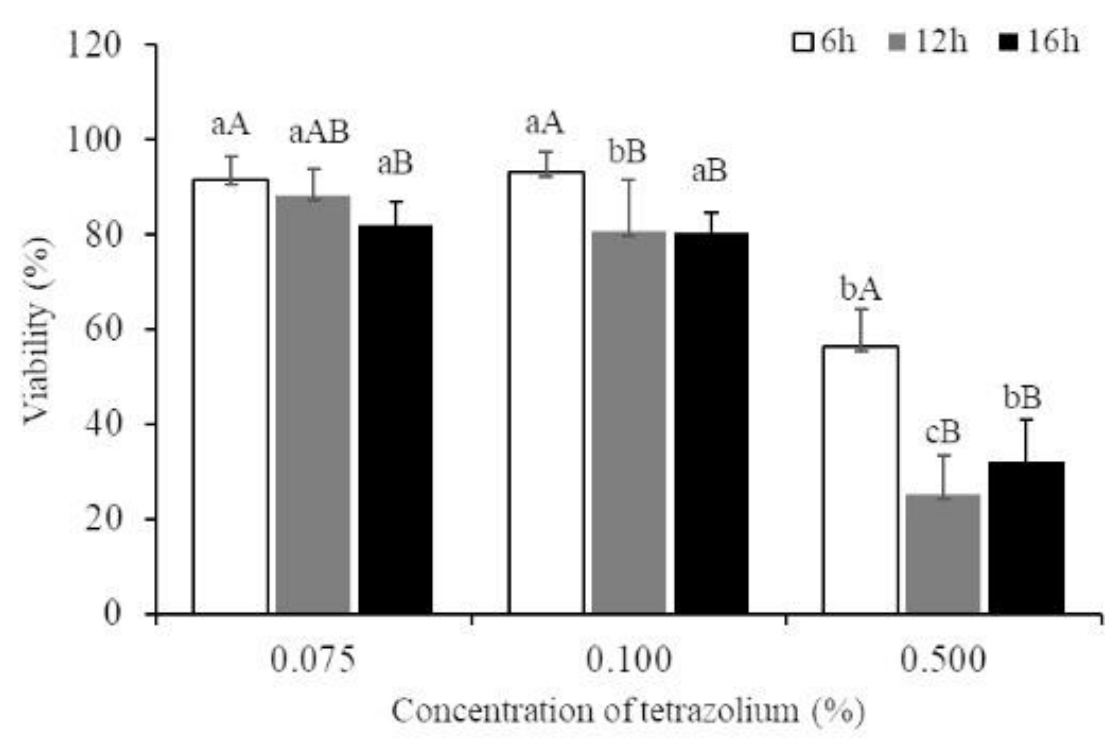

Figure 3. Means viability values of Tamarindus indica $\mathrm{L}$ under the time $\mathrm{x}$ tetrazolium salt concentration interaction. Mean followed by the same lowercase letters between concentrations and uppercase letters between times do not differ by Tukey's test ( $p \leq 0.05$ ). 
The best responses to the tetrazolium test occurred when the embryos were exposed to the $0.075 \%$ and $0.1 \%$ concentrations for 6 h (Figure 3). On the other hand, results were not satisfying when the $0.5 \%$ concentration was used in any of the times studied, causing a reduction in seed viability percentage.

Thus, longer soaking times and higher salt concentrations translate into stronger embryo staining. The shorter soaking times and the $0.1 \%$ concentration allowed an adequate visualization of staining and higher precision in the distinction between viable and non-viable embryos for both lots. The $0.5 \%$ tetrazolium concentration, regardless of immersion time, created an intense staining (Table 2), making it more difficult to differentiate between viable and non-viable embryos. This was observed by T. L. Lima and Cunha (2019) in S. polyphylla, at the $0.5 \%$ concentration, for which all soaking and immersion times resulted in strong staining, which made it difficult to interpret and differentiate normal and firm tissues from those in deterioration processes.

\section{Table 2}

Staining pattern of Tamarindus indica L. embryos immersed in tetrazolium salt solution at three concentrations $(0.075,0.1$ and $0.5 \%)$, for three periods $(6 ; 12$ and $16 \mathrm{~h})$

\begin{tabular}{|c|c|c|c|c|c|c|}
\hline \multirow[b]{2}{*}{ Lot } & \multirow[b]{2}{*}{$\begin{array}{l}\text { Staining } \\
\text { Time (h) }\end{array}$} & \multirow[b]{2}{*}{$\begin{array}{l}\text { Tetrazolium } \\
\text { Solution (\%) }\end{array}$} & \multirow[b]{2}{*}{ Unstained } & \multicolumn{3}{|c|}{ Staining Pattern (\%) } \\
\hline & & & & Weak & Adequate & Strong \\
\hline \multirow{9}{*}{2018} & 6 & 0.075 & 4 & 9 & 87 & - \\
\hline & 12 & 0.075 & 4 & - & 86 & 10 \\
\hline & 16 & 0.075 & 4 & - & 22 & 74 \\
\hline & 6 & 0.1 & - & - & 91 & 9 \\
\hline & 12 & 0.1 & 4 & - & 67 & 29 \\
\hline & 16 & 0.1 & 4 & - & 73 & 23 \\
\hline & 6 & 0.5 & - & - & 45 & 55 \\
\hline & 12 & 0.5 & 4 & - & 28 & 68 \\
\hline & 16 & 0.5 & - & - & 16 & 84 \\
\hline \multirow{9}{*}{2019} & 6 & 0.075 & - & 12 & 88 & - \\
\hline & 12 & 0.075 & - & - & 90 & 10 \\
\hline & 16 & 0.075 & - & - & 70 & 30 \\
\hline & 6 & 0.1 & - & - & 92 & 8 \\
\hline & 12 & 0.1 & - & - & 68 & 32 \\
\hline & 16 & 0.1 & - & - & 45 & 55 \\
\hline & 6 & 0.5 & - & - & 54 & 46 \\
\hline & 12 & 0.5 & - & - & 27 & 73 \\
\hline & 16 & 0.5 & - & - & 33 & 67 \\
\hline
\end{tabular}


Ourfindingsagree with those described by Pereira et al. (2020), who investigated $P$. stipulacea seeds and stated that staining patterns vary with the solution concentration (0.05, 0.075, and $0.1 \%)$ and incubation time (2, 4 , and $6 \mathrm{~h}$ ). while tissues with lighter shades were found in a shorter immersion time, the light-pink color was associated with the $0.075 \%$ concentration indicated to evaluate viability and vigor for $4 \mathrm{~h}$ of salt immersion.

The concentrations of 0.075 and $0.1 \%$ in the study of Carvalho et al. (2017) with $L$. ferrea seeds showed better viability means in the period of $3 \mathrm{~h}$ of salt immersion in the same concentrations. Likewise, Sousa et al. (2017) recommend the $0.075 \%$ tetrazolium concentration for $90 \mathrm{~min}$ of immersion for $P$. pyramidalis seeds.
Obtaining data on the initial quality of T. indica seeds is important to conduct the tetrazolium tests, since the complementary responses provided by the germination and/or emergence tests will help in the choice of the best tetrazolium salt concentration (Pereira et al., 2020).

The 2018 and 2019 seed lots showed moisture degrees of $13 \%$ and $11 \%$, respectively. Seeds of this species are classified as orthodox, which enables storage with the maintenance of physiological quality from harvesting to sowing (A. V. C. Silva et al., 2016). However, this variation is considered tolerable (Marcos, 2015), as evidenced by the similarities between the lots in the germination and vigor tests (Table 3 ).

Table 3

Physiological characterization of Tamarindus indica L. lots

\begin{tabular}{|ccccccc|}
\hline Year & FGC & G & GSI & FEC & E & ESI \\
\hline 2018 & $61.0 \mathrm{a}$ & $98.0 \mathrm{a}$ & $6.61 \mathrm{a}$ & $69.0 \mathrm{a}$ & $79.0 \mathrm{~b}$ & $2.11 \mathrm{a}$ \\
\hline 2019 & $54.0 \mathrm{a}$ & $99.0 \mathrm{a}$ & $6.27 \mathrm{a}$ & $51.0 \mathrm{~b}$ & $94.0 \mathrm{a}$ & $2.12 \mathrm{a}$ \\
\hline CV (\%) & 19.21 & 2.19 & 8.43 & 14.27 & 7.95 & 9.74 \\
\hline LSD & 19.1 & 3.7 & 0.94 & 14.8 & 11.9 & 0.36 \\
\hline Year & $\mathrm{RL}$ & $\mathrm{SHL}$ & $\mathrm{SDL}$ & $\mathrm{RDW}$ & SDW & TDW \\
\hline 2018 & $21.36 \mathrm{a}$ & $9.64 \mathrm{~b}$ & $30.99 \mathrm{a}$ & $0.40 \mathrm{a}$ & $0.64 \mathrm{a}$ & $1.04 \mathrm{a}$ \\
\hline 2019 & $16.92 \mathrm{a}$ & $11.11 \mathrm{a}$ & $28.03 \mathrm{a}$ & $0.38 \mathrm{a}$ & $0.69 \mathrm{a}$ & $1.06 \mathrm{a}$ \\
\hline CV (\%) & 15.57 & 4.88 & 10.94 & 9.32 & 10.94 & 9.98 \\
\hline LSD & 5.15 & 0.88 & 5.59 & 0.06 & 0.13 & 0.18 \\
\hline
\end{tabular}

Means followed by the same letter do not differ by the t test (LSD) $(p<0.05)$. LSD, least significant difference. Germination $(\mathrm{G} \%)$, emergence (E\%), first germination count (FGC), first emergency count (FEC), germination speed index (GSI), emergence speed index (ESI), root length (RL), shoot length (SHL) seedling length (SDL), root dry weight (RDW), shoot dry weight (SDW), and total dry weight (TDW). 
According to the data shown in Table 3 , there was no variation between the lots for germination, first germination count, germination speed index, emergence speed index, shoot length or total dry weight, indicating similarity in physiological quality. However, the emergence was $19 \%$ higher in the 2019 lot, while first emergence count was $35.2 \%$ higher in the 2018 lot.

Vigor tests are used for ranking as well as to detect useful information in decisionmaking regarding the destination of a seed lot (Bezerra et al., 2019). Several studies described differences in vigor as measured by the emergence test, first emergence count and germination speed index. C. R. L. Lima, Bruno, Silva, Pacheco and Alves (2014) evaluated the physiological quality of seeds from $P$. pyramidalis mother trees and found differences in vigor based on the first count and emergency speed index. In Amburana cearenses, as reported by Guedes et al. (2013), field emergence, emergence first count and emergence speed index were accurate in separating the lots into different levels of vigor.

In this sense, the initial evaluation of lots (Table 3) was performed to identify those with higher and lower physiological potential. Based on the emergency percentage, the 2019 lot was the most vigorous, whereas first emergence count was higher in the 2018 lot, but both showed to be vigorous. This is important, as highlights Jeromini, Pereira, Martins and Silva (2020) who concluded that in a laboratory or greenhouse, it is desirable to reduce the germination and emergence time, since the faster these processes occur, the shorter the seeds will remain vulnerable to adverse environmental factors, e.g., microorganism attack.
Determining viability and vigor in $T$. indica seeds by germination and emergence tests is lengthy process that takes over 20 days for conclusion, which renders decisionmaking regarding the use of seeds for storage, sowing, sale, or their discard difficult. In this respect, Carvalho et al. (2017) emphasized the importance of the tetrazolium test in determining seed viability and vigor in several forest species due to its reliability and speed of results.

The $0.1 \%$ concentration allowed us to distinguish the lot obtained in 2019 as the most vigorous. This result was similar to that obtained by the emergence test, which differentiated the lots in their response to less control of environmental factors. In $E$. velutina seeds, Willd Cunha and Gomes (2015) also observed close values between the germination and tetrazolium test, with $91 \%$ of viable seeds and $89 \%$ of germination at the $0.075 \%$ concentration. The tetrazolium test was shown to be efficient in the evaluation of Caesalpinia pulcherrima (L.) SW seeds by Ferro et al. (2019) at the concentrations of 0.075 and $0.1 \%$, where germination values did not differ.

After the analysis of different concentrations and soaking times, it was possible to establish classes of viability and vigor for T. indica embryos (Figure 4) based on the staining patterns, which varied from light pink to white (discolored). Accordingly, they were classified as viable and non-viable embryos, respectively, observing the following order: Class 1 - viable and vigorous embryos (Figure 4 A-B); Class 2 - Viable seeds (Figure $4 \mathrm{C}$ to F); Class 3 - Non-viable seeds (Figure 4 $\mathrm{G}$ to $\mathrm{L})$. 


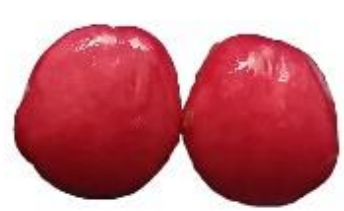

A

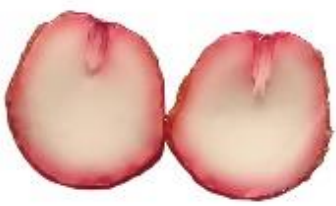

C
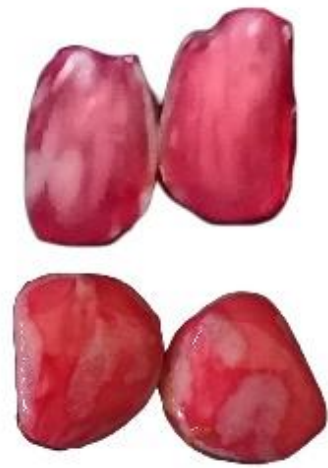

E

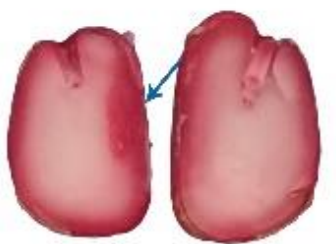

E
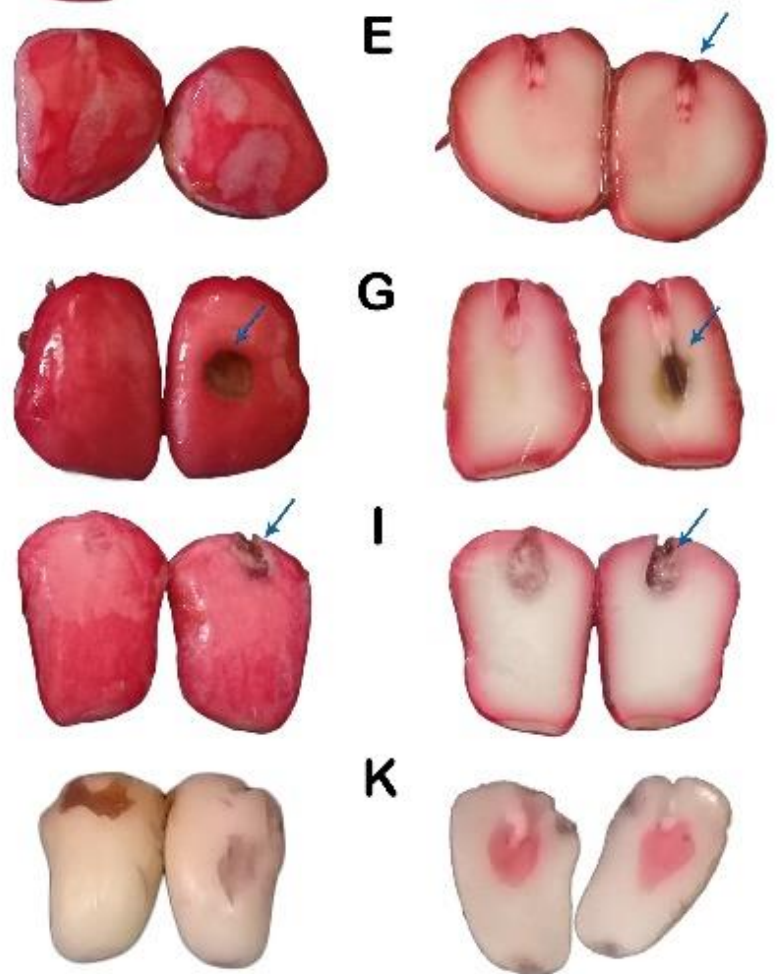

G

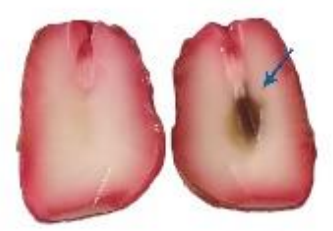

I

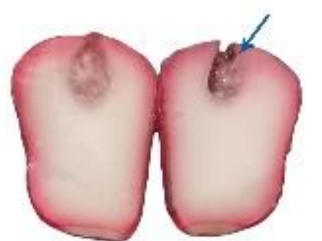

K

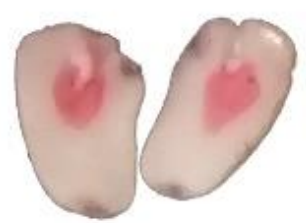

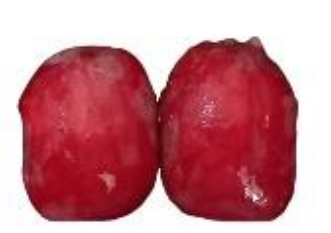

B

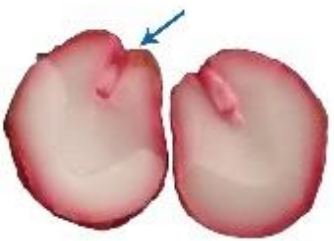

D

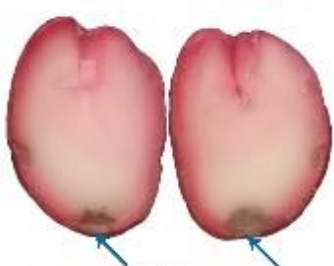

F

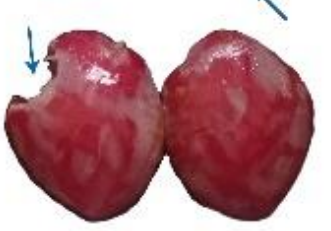

H
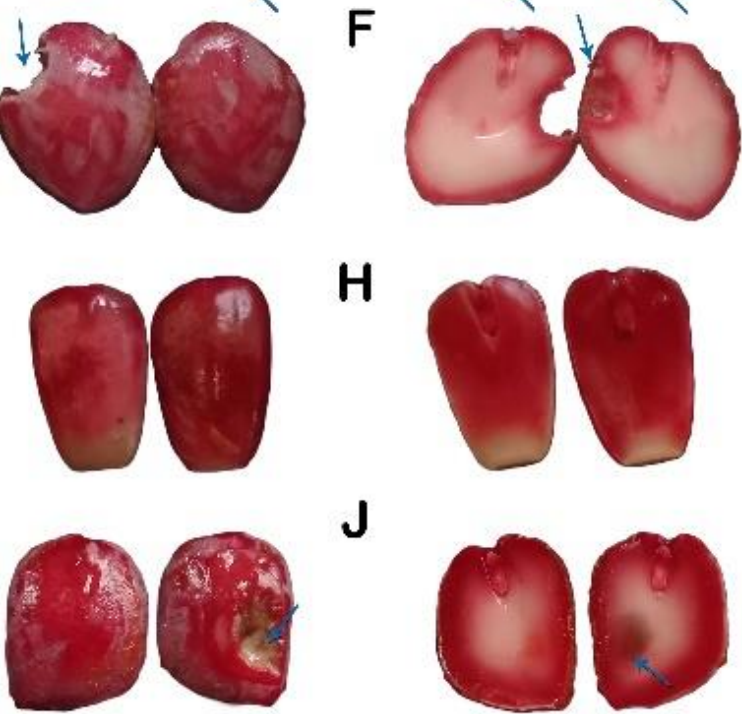

$\mathbf{J}$

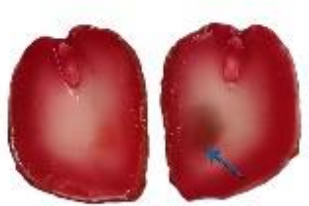

L

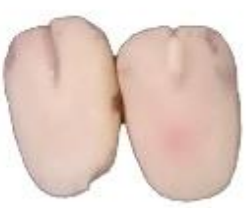

Figure 4. Vigor and viability classes of Tamarindus indica L. embryos in the tetrazolium test (A and $\mathrm{B}$ - viable and vigorous embryos; $\mathrm{C}$ to $\mathrm{F}$ - viable embryos; $\mathrm{G}$ to $\mathrm{J}$ - non-viable embryos and, $\mathrm{K}-\mathrm{L}-$ dead embryos). The arrows indicate lesions in the embryos.

The intensity of seed staining in the tetrazolium test varies between species. Moraes et al. (2019) highlight that the red or light-pink colors indicate a viable tissue and the terminology used to determine the observed seed colors in the tetrazolium test is generally established by the authors. Therefore, they may vary among the different studies.

The choice of the appropriate method for the tetrazolium test may be based on the 
ease of identification for viable and non-viable tissues and in its ability to differentiate seed vigor. The colors differences observed in the seeds after staining in tetrazolium solution are the main features to be considered in the interpretation of results of specific tests (Santos, Vieira, \& Panobianco, 2019).

The tetrazolium test for $T$. indica seeds allowed discriminate both lots at the $0.1 \%$ concentration in terms of viability, with the possibility of obtaining results in $59 \mathrm{~h}$ [ $1 \mathrm{~h}$ for seed preparation (manual scarification), $48 \mathrm{~h}$ for preconditioning (water soaking), 1 $\mathrm{h}$ for seed-coat removal, $6 \mathrm{~h}$ for immersion in tetrazolium solution, $1 \mathrm{~h}$ for sectioning the embryos and about $2 \mathrm{~h}$ to evaluate the 100-embryos sample). On the other hand, in the germination and vigor tests for this species, results were obtained in up to 30 days. Therefore, considering that the viability results were similar between the germination and tetrazolium tests, this methodology is recommended to rapidly estimate the viability of $T$. indica seeds.

\section{Conclusion}

To perform the tetrazolium test in $T$. indica seeds, the seeds must be manually scarified, followed by direct moistening in distilled water for $48 \mathrm{~h}$ at $30^{\circ} \mathrm{C}$ and seed-coat removal.

The viability of $T$. indica seeds may be evaluated using the $0.1 \%$ concentration of tetrazolium salt at $40{ }^{\circ} \mathrm{C}$ for six hours of immersion;

The tetrazolium test showed to be adequate to differentiate $T$. indica seed lots in terms of viability.

\section{Acknowledgments}

The present study was supported by the Coordination for the Improvement of Higher Education Personnel - Brazil (CAPES) - Finance Code 001, through the doctoral fellowship granted to the first author (LNC).

\section{References}

Bezerra, A. C., Zuza, J. F. C., Barbosa, L. S., Oliveira, L. C. L., Santos, E. N., \& Alves, E. U. (2019). Qualidade física, fisiológica e anatomia do tegumento de Fabaceae. Meio Ambiente (Brasil), 1(2), 41-47.

Carvalho, S. M. C., Torres, S. B., Benedito, C. P., Nogueira, N. W., Souza, A. A. T., \& Souza, M. L., Neta. (2017). Viability of Libidibia ferrea (Mart. ex Tul.) L.P. Queiroz var. ferrea) seeds by tetrazolium test. Journal of Seed Science, 39(1), 7-12. doi: 10.1590/23171545v39n1163784

Cunha, M. C. L., \& Gomes, I. H. R. A. (2015). Viabilidade de sementes de Erythrina velutina Willd pelo teste de tetrazólio. Nativa, 3(3), 196-200. doi: 10.31413/ nativa.v3i3.2304

Ferreira, A. F. A., Monteiro, L. N. H., Rodrigues, M. G. F., Oliveira, N. B., \& Boliani, A. C. (2018). In vitro cultivation of Tamarindus indica L.: explants obtention and contamination in culture médium. Comunicata Scientiae, 9(2), 298-302. doi: 10.14295/CS.v9i2.2602

Ferro, J. S., Rocha, D. F., Melo, J. L. A. Jr., Araújo, J. C., Neto, Silva, J. V., \& Pavão, J. M. S., Jr. (2019). Germination and viability of seeds of Caesalpinia pulcherrima newly harvested and stored. Journal of Agricultural Science, 11(7), 73-85. doi: 10.5539/jas.v11n7p73 
França, J. B., Neto, \& Krzyzanowski, F. C. (2019). Tetrazolium: an importante test for physiological seed quality evaluation. Journal of Seed Science, 41(3), 359-366. doi: 10.1590/2317-1545v41n3223104

Guedes, R. S., Alves, E. U., Costa, E. M.T., SantosMoura, S. S., Silva, R. S., \& Cruz, F. R. S. (2013). Avaliação do potencial fisiológico de sementes de Amburana cearensis (Allemão) A. C. Smith. Bioscience Journal, 29(4), 859-866.

Jeromini, T.S., Pereira, T.S., Martins, C.C., \&Silva, G. Z. (2020). Superação de dormência de sementes de Bauhinia scandens. Semina: Ciências Agrárias, 41(4), 1189-1198. doi: 10.5433/1679-0359.2020v41n4 p1189

Lima, C. R. L., Bruno, R. L. A., Silva, K. R. G., Pacheco, M. V., \& Alves, E. U. (2014). Qualidade fisiológica de sementes de diferentes árvores matrizes de Poincianella pyramidalis (Tul.) L. P. Queiroz. Revista Ciência Agronômica, 45(2), 370-378. doi: 10.1590/S1806-66 902014000200019

Lima, T. L., \& Cunha, M. C. L. (2019). Viabilidade de sementes de Senegalia polyphylla (DC.) Britton \& Rose pelo teste do tetrazólio. Ciência Agrícola, 17(3), 23-30. doi: 10.28998/rca.v17i3.7406

Maguire, J. D. (1962). Speed of germination-aid in selection and evaluation for seedling emergence and vigor. Crop Science, 2(1), 176-177. doi: 10.2135/cropsci1962.0011 183X000200020033x

Marcos, J., Fo. (2015). Fisiologia de sementes de plantas cultivadas. Londrina: ABRATES.

Ministério da Agricultura, Pecuária e Abastecimento (2009). Regras para análise de sementes. Brasília: MAPA/ACS.
Moraes, P. H. F., Cavalcante, L. V., Albuquerque, A. S., Rodrigues, A. M. C., Melo, J. L. A., Jr., \& Melo, L. D. F. A. (2019). Preparo da semente de colubrina para execução do teste de tetrazólio. Revista Verde, 14(5), 625-628. doi: 10.18378/rvads.v14i5.7599

Mozumder, S., Khan, B. M., \& Rahman, M. R. (2018). Pre-sowing treatments for improved germination and growth performance of Tamarindus indica L. in Bangladesh. Asian Journal Biological Science, 11(3), 120-129. doi: 10.3923/ ajbs.2018.120.129

Oliveira, E. P., Oliveira, E. P. de, Costa, C. B., Santos, G. M. S. S., \& Guariz, H. R. (2017). Superação de dormência em sementes de Tamarindus indica L. submetidas a diferentes tratamentos pré-germinativos. RevistaCientíficaEletrônicadeAgronomia, 32. Retrieved from http://faef.revista.inf.br/ imagens_arquivos/arquivos_destaque/ rY4BXHnVEQwajtr_2018-1-25-15-4-22. pdf

Paim, L. P., Avrella, E. D., Luchesse, J., Freitas, E. M., Lazarotto, M., \& Fior, C. S. (2019). Seed analysis of Lupinus albescens Hook. \& Arn. Iheringia, Série Botânica, 74, e2019010. doi: 10.21826/2446-8231 2019v74e2019010

Pereira, K. T. O., Paiva, E. P., Souza, M. L., Neta, Benedito, C. P., \& Torres, S. B. (2020). Physiological quality evaluation of Piptadenia stipulacea (Benth.) Ducke seeds by tetrazolium test. Revista Ciência Agronomica, 51(1), e20196712. doi: 10. 5935/1806-6690.20200019

Ramchander, T., Rajkumar, D., Sravanprasad, M., Venkateshwarlu, G., Dhanalakshmi, C. H., \& Arjun. (2012). Antidiabetic activity of aqueous methanolic extracts of leaf of 
Tamarindus indica. International Journal of Pharmacognosy and Phytochemical Research, 4(1), 5-7.

Santos, F. S., Vieira, E. S. N., \& Panobianco, M. (2019). Tetrazolium test for Pinus taeda: preparation, staining, and seed viability classes. Pesquisa Agropecuária Brasileira, 54, e01088. doi: 10.1590/S1678-3921. pab2019.v54.01088

Silva, A. V. C., Soares, A. N. R., Santos, P. S., Nascimento, A. L. S., Vitória, M. F., Oliveira, J. M. S. P.,... Rabbani, A. R. C. (2016). Physiological potential of tamarind seeds subjected to stress conditions and storage. African Journal of Agricultural Research, 11(30), 2761-2767. doi: 10.5897/AJAR2016.11321

Silva, D. D. A., Machado, C. G., Cruz, S. C. S., Vespucci, I. L., \& Araujo, Y. J. D. (2017). Temperatura e substrato para o teste de germinação de sementes de tamarindo. Revista Espacios, 38(14), 4-10.

Singh, A. K. (2015). Morpho-taxonomic approaches of Indian date (Tamarindus indica L.) Seedling - a multipurpose tree. International Journal of Advanced Research, 3(6), 625-631. doi: 10.21474/ IJAR01
Sousa, D. M. M., Bruno, R. L. A., Dornelas, C. S. M., Alves, E. U., Andrade, A. P., \& Nascimento, L. C. (2010). Caracterização morfológica de frutos e sementes e desenvolvimento pós-seminal de Tamarindus indica L. Leguminosae: caesalpinioideae. Revista Árvore, 34(6), 1009-1015. doi: 10.1590/ S0100-676 22010000600006

Sousa, D. M. M., Bruno, R. L. A., Silva, K. R. G., Torres, S. B., \& Andrade, A. P. (2017). Viabilidade e vigor de sementes de Poincianella pyramidalis (Tul.) L. P. Queiroz pelo teste de tetrazólio. Revista Ciência Agronômica, 48(2), 381-388. doi: 10.5935/1806-6690.20170044

Yusuf, S. C., Zakawa, N. N., Tizhel, T. D., Timon, D., Obot, J. J., \& Linus, S. G. (2019). Dormancy breaking and the influence of gibberellic acid on the early growth of Tamarindus indica Seedlings in Mubi, Nigeria. Asian Journal of Soil Science and Plant Nutrition, 5(2), 1-6. doi: 10.9734/ AJSSPN/2019/v5i230063

Zorzal, T. A., Fantinato, D. E., Campos, L. M., Luz, A. C. C., \& Corte, V. B. (2015). Teste do tetrazólio para estimativa da viabilidade de sementes. Natureza on line, 13(3), 144149. 